\title{
A MORPHOMETRICAL STUDY OF FORAMEN MAGNUM IN ADULT HUMAN DRIED SKULL OF SOUTH INDIAN POPULATION
}

\section{Ashwini $\mathrm{C}^{1}$, Pratik Khona *2.}

${ }^{1}$ Assistant professor, Dept of Anatomy, Gadag Institute of Medical Sciences, Gadag, Karnataka, India.

${ }^{{ }^{2}}$ Assistant professor, Dept of Anatomy, Gadag Institute of Medical Sciences, Gadag, Karnataka, India.

\section{ABSTRACT}

Introduction: Foramen magnum is a wide opening present in the occipital bone of the cranium. Morphometry of foramen magnum are important because vital structures pass through it and for sex determination of skulls. The aim of the present study was to conduct morphometric analysis of foramen magnum.

Materials and Methods: Completely ossified 162 adult human dry skulls of unknown age and sex were taken from the Department of Anatomy of Gadag institute of medical sciences, Gadag. The skull samples which were deformed were excluded from the study. The antero-posterior and transverse diameters were measured using a digital vernier caliper graded upto $0.01 \mathrm{~mm}$. The statistical analysis was carried out and the results were tabulated. Results: The longitudinal diameter of the foramen magnum in the present study was between $31-36 \mathrm{~mm}$ with a mean of $33 \mathrm{~mm} \pm 1.4$ (Mean $\pm \mathrm{SD}$ ). The transverse diameter was between $25 \mathrm{~mm}-30 \mathrm{~mm}$ with a mean of $27 \mathrm{~mm}+$ 1.6.

Conclusion: Knowledge of foramen magnum measurements are useful for anatomists, neurosurgeons, radiologists, and also anthropologists. The data obtained will be useful to the neurosurgeon in understanding the anatomy of craniovertebral junction in a newly described transcondylar approach for brain stem lesion particularly in preoperative assessment.

KEY WORDS: Skull, Foramen Magnum, Morphometry.

Address for Correspondence: Dr. Pratik Khona, Assistant Professor, Department of Anatomy, Gadag Institute of Medical Sciences, Gadag, Karnataka, India. Mob: 9916575877

E-Mail: drpratikkhona@gmail.com

Access this Article online

Quick Response code

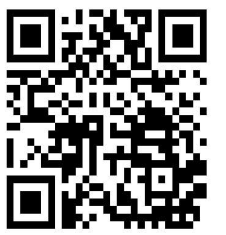

DOI: $10.16965 /$ ijar.2017.477

Journal Information

International Journal of Anatomy and Research

ICV for 2016 ISSN (E) 2321-4287 | ISSN (P) 2321-8967

90.30 https://www.ijmhr.org/ijar.htm DOI-Prefix: https://dx.doi.org/10.16965/ijar

\section{Article Information}

Received: 21 Oct 2017

Peer Review: 22 Oct 2017

Revised: None
Accepted: 18 Nov 2017

Published (O): 05 Jan 2018

Published (P): 05 Jan 2018

\section{INTRODUCTION}

Foramen magnum term is derived from the Latin word called as 'Great hole'. Foramen magnum is a wide opening present in the occipital bone of the cranium. It is placed anteromedially in the occipital bone[1]. Various shapes of foramen magnum have been noted like oval, rounded, tetragonal, pentagonal, hexagonal, and irregular. Among this oval shape is the commonest one $[2,3]$.
The boundary of foramen magnum is formed by all parts of occipital bone that is two condylar parts, squamous part and occipital part. Anteroposterior diameter of foramen magnum is more than the transverse diameter. Anteriorly on each side of foramen magnum oval occipital condyles are present, which project downwards to articulate with the superior articular facets on the lateral masses of the atlas. Occipital condyle is placed obliquely so that anterior end is nearer 
to median plane than the posterior end. Above the anterior part of the occipital condyle hypoglossal canal lies which transmit hypoglossal nerve, meningeal branch of ascending pharyngeal artery[1].

Alar ligament of dens divides the foramen magnum into anterior osseo-ligamentous compartment and posterior neurovascular compartment. Vital structures passing through the foramen magnum are medulla oblongata with the meninges, fourth part of vertebral arteries, anterior and posterior spinal arteries and spinal roots of accessory nerves and occasionally cerebellar tonsil may project on each side of the brain stem[1].

In a conditions like achondroplasia, foramen magnum brain herniation, meningiomas and atlanto-occipital fusion the vital structure that pass through it may be compressed, so the dimensions of the foramen magnum are clinically important. Transverse diameter of foramen magnum will be increased in Arnold chiari malformation. Knowledge of foramen magnum measurement is important clinically[4]. With the advance in neuroimaging technique craniovertebral abnormalities diagnosis is increased which has increased the interest of neuro surgeons to do cranio vertebral surgeries.

The measurements are helpful for neurosurgeons for performing lateral transcondylar surgical approaches for reaching lesions in the middle and posterior part of cranial base[5]. Hence, the present morphometric study of foramen magnum among south Indian population has been undertaken. It is hopeful that the data will be valuable particularly for the neuro-surgeons, radiologists and orthopae-dicians particularly in preoperative assessment.

\section{MATERIALS AND METHODS}

Completely ossified 162 adult human dry skulls of unknown age and sex were taken from the Department of Anatomy of Gadag institute of medical sciences, Gadag. The skull samples which were deformed were excluded from the study.

The anteroposterior and transverse diameters were measured using a digital vernier caliper graded upto $0.01 \mathrm{~mm}$. Measurements were done using following bony landmarks on the skull.
Basion middle point of the anterior margin of foramen magnum) and Opisthion (Opisthion is middle point of posterior margin of foramen magnum). Anteroposterior diameter of foramen magnum is the distance measured between Basion and opisthion. Transverse diameter of foramen magnum is the distance measured at right angles to anteroposterior diameter of foramen magnum.

\section{Other parameters recorded as follows}

1. Anterior intercondylar distance- distance between anterior tips of right and left occipital condyles.

2. Posterior intercondylar distance- distance between posterior tips of right and left occipital condyles.

The Statistical methods: Results were expressed as mean \pm standard deviation and range. Unpaired' $t$ ' test was used to compare between right and left. $P$ value of 0.005 or less was considered for statistical significance.

\section{OBSERVATIONS AND RESULTS}

The statistical analysis was carried out and the results have been tabulated and represented in the form of bar diagrams.

Table 1: The mean antero-posterior, transverse diameter of foramen magnum along with standard deviation.

\begin{tabular}{|l|c|c|}
\hline $\begin{array}{c}\text { Number of skulls- } \\
162\end{array}$ & $\begin{array}{c}\text { Anteroposterior } \\
\text { diameter of Foramen } \\
\text { magnum }(\mathrm{mm})\end{array}$ & $\begin{array}{c}\text { Tranverse diameter of } \\
\text { foramen magnum }(\mathrm{mm})\end{array}$ \\
\hline Mean & 33.7 & 27 \\
\hline Standard deviation & 1.4 & 1.6 \\
\hline Minimum & 31 & 25 \\
\hline Maximum & 36 & 30 \\
\hline
\end{tabular}

The longitudinal diameter of the foramen magnum in the present study is between $31 \mathrm{~mm}-36 \mathrm{~mm}$ with a mean of $33 \mathrm{~mm} \pm 1.4$ $($ Mean $\pm S D)$. The transverse diameter is between $25 \mathrm{~mm}-30 \mathrm{~mm}$ with a mean of $27 \mathrm{~mm}+1.6$

Table 2: Mean length of anterior and posterior intercondylar distance along with SD.

\begin{tabular}{|c|c|c|c|c|c|}
\hline & $\begin{array}{c}\text { Number of } \\
\text { skulls }\end{array}$ & $\begin{array}{c}\text { Mean in } \\
\mathrm{mm}\end{array}$ & $\begin{array}{c}\text { Minimum } \\
\text { in } \mathrm{mm}\end{array}$ & $\begin{array}{c}\text { Maximum } \\
\text { in } \mathrm{mm}\end{array}$ & $\begin{array}{c}\text { Standard } \\
\text { deviation }\end{array}$ \\
\hline $\begin{array}{c}\text { Posterior } \\
\text { intercondylar } \\
\text { Distance }\end{array}$ & 162 & 31.63 & 29 & 42 & 2.93 \\
\hline $\begin{array}{c}\text { Anterior } \\
\text { intercondylar } \\
\text { distance }\end{array}$ & 162 & 15.78 & 14 & 19 & 1.266 \\
\hline
\end{tabular}


The present study indicates that, the mean anterior intercondylar distance between two condyles in 162 skulls was found to be 15.78 $\mathrm{mm}$ with a range of $14-19 \mathrm{~mm}$ and a standard deviation of 1.26. Mean posterior intercondylar distance between the two condyles in 162 skulls was found to be $31.63 \mathrm{~mm}$ ranging from $19-42$ $\mathrm{mm}$ having a standard deviation of 2.93 .

Graph 1: Anteroposterior and transverse diameter of foramen magnum.

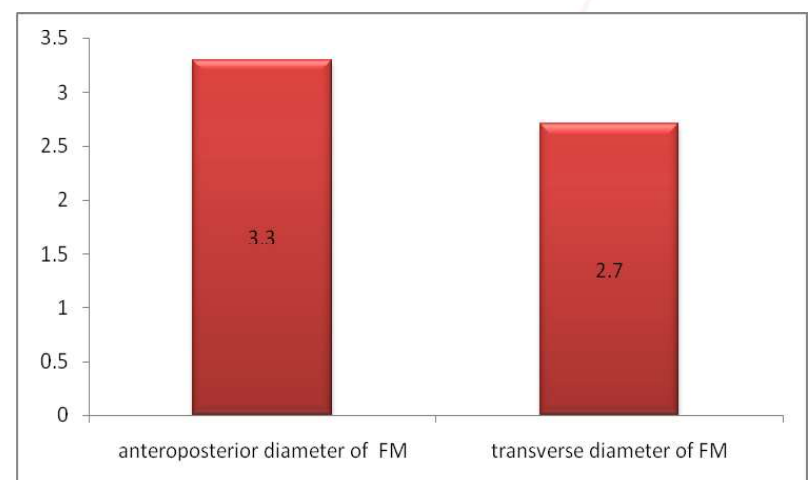

Graph 2: Anterior and posterior intercondylar distance.

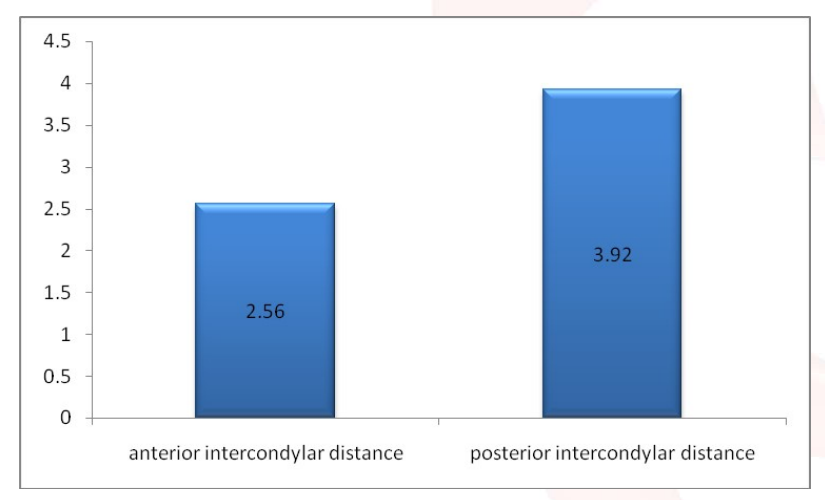

\section{DISCUSSION}

Foramen magnum is a major opening in the posterior cranial fossa of the skull, many vital structures passes through it. Morphometrical study of foramen magnum and occipital condyle was done in the 162 human skulls.

In the present study the mean longitudinal diameter of foramen magnum was $33 \mathrm{~mm}$ which is similar to Muthukumar et al and Muralidhar et al study was done on Karnataka human skulls $[5,6]$. However the values are slightly lower than the observations made by Radhika et al and Sanjukta et al which were also done on south Indian population. The mean value of anteroposterior diameter in their study is $35 \mathrm{~mm}$ and transverse diameter is $29 \mathrm{~mm}[3,6]$.

Berge and Bergmann reported an average sagittal diameter of $34 \mathrm{~mm}$ and an average transverse diameter of $29 \mathrm{~mm}$ [7]. Philipp Gruber, in his study on skulls from Western Europe found the sagittal diameter ranges $30 \mathrm{~mm}$ to 43 $\mathrm{mm}$ with mean of $36.6 \mathrm{~mm}$. The transverse diameter ranges from $25 \mathrm{~mm}$ to $39 \mathrm{~mm}$ with the mean of $31.1 \mathrm{~mm}[8]$.

In the Morphometric analysis of the foramen magnum in human skulls of Brazilian individual found that mean antero-posterior diameter of foramen magnum was $35.7 \mathrm{~mm}$ in male and 35.1 $\mathrm{mm}$ in female. The transverse diameter was 30.3 $\mathrm{mm}$ in male, $29.4 \mathrm{~mm}$ in female[9].

Table 3: The anteroposterior and transverse diameter of foramen magnum of present study were compared with previous studies.

\begin{tabular}{|l|c|c|}
\hline \multicolumn{1}{|c|}{ Authors } & $\begin{array}{c}\text { Anteroposterior } \\
\text { Diameter (mm) }\end{array}$ & $\begin{array}{c}\text { Transverse } \\
\text { Diameter (mm) }\end{array}$ \\
\hline Muralidhar et.al (2014) [14] & 33.4 & $27.4 \mathrm{~mm}$ \\
\hline Muthukumar et.al (2005) [5] & 33.3 & 27.9 \\
\hline Suazo, G. et.al (2009) [18] & 36.05 & 30.05 \\
\hline Avci et. al (2010) [15] & 34.5 & 29 \\
\hline Kizilkant et. al (2006) [11] & 34.8 & 29.6 \\
\hline Murshed et.al (2003) [2] & 35.9 & 30.45 \\
\hline Tubbs et. al (2010) [16] & 31 & 2.7 \\
\hline Manoel et. al (2009) [19] & 35.4 & 29.85 \\
\hline Osunwoke E.A (2012) [17] & 36.1 & 29.5 \\
\hline Radhika et. al (2014) [6] & 35.3 & 29.4 \\
\hline Sanjukta et. al (2015) [13] & 35.3 & 29.49 \\
\hline \multicolumn{1}{|c|}{ Present study } & $\mathbf{3 3}$ & $\mathbf{2 7}$ \\
\hline
\end{tabular}

In a study conducted at St.John Medical College, Bangalore on 350 skulls (175 males, 175 females) for foramen magnum dimensions showed. In male skulls antero-posterior diameter of foramen magnum was varied from $2.8-4.1 \mathrm{~cm}$ with a mean of $3.42 \pm 0.24 \mathrm{~cm}$, transverse diameter was varied from $2.3-3.6$ $\mathrm{cm}$ with a mean of $2.85 \pm 0.23 \mathrm{~cm}$ and the area of foramen magnum was varied from $5.6-11 \mathrm{~cm}$ with a mean of $7.69 \mathrm{~cm}$. In female skulls antero posterior diameter of foramen magnum was varied form $2.2-3.3 \mathrm{~cm}$ with a mean of $2.8 \pm$ $0.22 \mathrm{~cm}$ and area of the foramen magnum was varied from $5.1-10 \mathrm{~cm}$ with a mean of $7.8 \pm$ $0.98 \mathrm{~cm}$ [2].From the above data, it can be stated that there is significant difference between anteroposterior and transverse diameters. The anteroposterior diameter is generally larger than transverse diameter.

Occipital condyles converge ventrally. There is significant difference between anterior and 
posterior intercondylar distance. This leads occipital condyle to have different anterior and posterior angles. This difference in the anterior and posterior intercondylar distance reflects the asymmetry in the orientation of occipital condyles which may affect the lateral approach. According to recent studies, condylectomy provides the wider angle of exposure.

Naderi in his metrical study of occipital condyles found that the mean anterior intercondylar distance and posterior intercondylar distance as $21.0 \pm 2.8 \mathrm{~mm}$ and $41.6 \pm 2.9 \mathrm{~mm}$, respectively[10]. Kizilkanat studied the occipital condyles, hypoglossal canal and foramen magnum in 59 Turkish-Caucasian skulls. In his study, the anterior and posterior intercondylar distances were $22.6 \mathrm{~mm}$ and $44.2 \mathrm{~mm}$ respectively[11]. Ozer MA demonstrated a study where morphological analysis of 704 sides of occipital bones of adult skulls was done. The mean anterior intercondylar distance and posterior intercondylar distance were found to be $20.9 \pm 3.6$ $\mathrm{mm}$ and $43 \pm 4 \mathrm{~mm}$ respectively[12].

Sanjukta et al found that in their study the mean anterior intercondylar distance between two condyles was $20.31 \mathrm{~mm}$ with a range from $11-34 \mathrm{~mm}$. and a standard deviation of 3.431.The Mean posterior intercondylar distance between two condyles was found to be 41.17 $\mathrm{mm}$ with the range being $32-49 \mathrm{~mm}$ and a standard deviation of 3.759[13].The results of present study is not similar to other studies done previously as depicted in table3.

\section{CONCLUSION}

Craniovertebral junction is formed by foramen magnum, occipital bone with its condyles. Many vital structures pass through it. It is clinically important for physicians to have a thorough knowledge of cranio vertebral junction.

In our present study we found that the mean vertical and transverse diameter $33 \mathrm{~mm}$ and 27 $\mathrm{mm}$ respectively. Anterior intercondylar distance and posterior intercondylar distance is $16 \mathrm{~mm}$ and $32 \mathrm{~mm}$ respectively.

Morphometrics of occipital condyle and foramen magnum is especially important for newly described transcondylar approach. The above said parameters will be useful for neurosurgeons, orthopaedicans and radiologists in planning surgical procedures involving the skull base.

\section{Conflicts of Interests: None}

\section{REFERENCES}

[1]. Standarding S. Gray's anatomy. The anatomical basis of clinical practice. 39th ed. London: Elsevier Churchill Livingstone; 2005 .460-65.

[2]. Murshed AK, Cicekcibasi AE, Tuncer I. Morphometric evaluation of the foramen magnum and variations in its shape: A study on computerized Tomographic images of normal adults. Turk J Med Sci., 2003; 33: 301-306

[3]. Chethan P, Prakash KG, Murlimanju BV, Prashant KU,Prabhu LV, Saralaya VV et.al Morphological Analysis and Morphometry of the Foramen Magnum: An Anatomical Investigation. Turkish Neurosurgery 2012; 22 (4): 416-19

[4]. Sgouros S, Goldin HJ, Hockely AD, Wake MJ, et al. Intracranial volume change in childhood. J Neurosurg 1999;91:610-16.

[5]. Muthukumar N, Swaminathan R, Venkatesh G,Bhamumathi SP. A morphometric analysis of the foramen magnum region as it relates to transcondylar approach. Actaneurochir (Wien), 2005; 147(8): 889- 95.

[6]. Radhika et al . Morphometric Study Of The Foramen Magnum In Adult Human Skulls In Indian Population .Asian J Med Clin Sci ,Mar - Aug 2014 Vol-3 (2): 68-72.

[7]. Berge JK,Bergmann RA. 2001. Variation in size and in symmetry of the foramina of the human skull. Clin Anat 14: 406-413.

[8]. Gruber P., HennebergM, Böni T. and Rühli F. J. Variability of Human Foramen Magnum Size. Anat Rec 2009; 292:1713-19.

[9]. Manoel C, Prado FB, Caria PHF, Groppo FC. Morphometric analysis of the foramen magnum in human skulls of brazilian individuals: its relation to gender. Braz. J. Morphol. Sci 2009; 26(2): 104-108.

[10]. Naderi S, Korman E, Citak G, Guvencer M, C Arman M, M S, Morphometric analysis of human occipital condyle. Clin Neurol Neurosurg, 107, 2005, 191199.

[11]. Kizilkanat E D, Boyan N, Morphometry of hypoglossal canal, occipital condyle and foramen magnum: abstract,Neurosurgery quarterly, 16(3), 2006, 121125.

[12].Ozer MA, Celik S, Govsa F, Ulusoy MO. Anatomical determination of a safe entry point for occipital screw usingthree-dimensional landmarks. Eur Spine J, 2011;20(9):1510-17.

[13]. Sahoo sanjukta et al Int. J. Pharm. Sci. Rev. Res., 33(2), July - August 201: 198-204.

[14]. Shepur PM, Magi M ,B Nanjudappa, Havaldar PP, Gogi P,Saheb S, Morphometric analysis of foramen magnum Int J Anat Res 2014, Vol 2(1):249-55.

[15]. Avic E, Dagtekin A, Ozturk AH, Kara E, Ozturk NC, Uluc $\mathrm{K}$ et.al. Anatomical variations of the foramen 
magnum,occipital condyle and jugular tubercle. Turk Neurosurg 2011; 21(2):181-190.

[16]. Tubbs RS, Griessenauer CJ, Loukas M, Shoja MM, Cohen-Gadol AA. Morphometrics analysis of foramen magnum: ananatomic study. Neurosurgery 2010; 66(2): 385-88.

[17]. Osunwoke EA, Oladipo GS, Gwunireama IU, Ngaokere JO.Morphometric analysis of the foramen magnum and jugularforamen in adult skulls in southern Nigerian population. Am. J. Sci. Ind. Res., 2012; 3(6): 446-448.
[18]. Suazo GIC, Russo PP, Zavando MDA, Smith RL, Sexual dimorphism in foramen magnum dimensions International Journal of Morphology; 2009; 27(1): 2123.

[19]. Manoel C, Prado FB, Caria PHF, Groppo FC.Morphometric analysis of the foramen magnum in human skulls of brazilian individuals: its relation to gender. Braz. J. Morphol. Sci 2009; 26(2): 104-108.

How to cite this article:

Ashwini C, Pratik Khona. A MORPHOMETRICAL STUDY OF FORAMEN MAGNUM IN ADULT HUMAN DRIED SKULL OF SOUTH INDIAN POPULATION. Int J Anat Res 2018;6(1.1):4831-4835. DOI: 10.16965/ijar.2017.477 